\title{
Pengaruh Kualitas Pelayanan dan Kedisiplin Pegawai Terhadap Kepuasan Masyarakat Pada Kantor Lurah Klender Jakarta Timur
}

\author{
Eulin Karlina $^{1}$, Oki Rosanto ${ }^{2}$, Nur Eka Saputra ${ }^{3}$ \\ ${ }^{1}$ Universitas Bina Sarana Informatika \\ e-mail: eulin.eka@bsi.ac.id \\ ${ }^{2}$ STMIK Nusa Mandiri \\ e-mail: oki.okr@bsi.ac.id \\ ${ }^{3}$ Universitas Bina Sarana Informatika \\ e-mail: donquixote.eka@gmail.com
}
Cara Sitasi: Karlina, E., Rosanto, O., \& Saputra, N. E. (2019). Pengaruh Kualitas Pelayanan dan Kedisiplin Pegawai Terhadap Kepuasan Masyarakat Pada Kantor Lurah Klender Jakarta Timur. Widya Cipta, 3(1), 7-16.

\begin{abstract}
In the organization of good service of efficient and efficient activities. The better the service will affect the level of satisfaction felt by the community. These efforts will increase higher. Enforcement of discipline makes work more effective and efficient. The research method used is descriptive quantitative by digging data using techniques, interviews and questionnaires. Test the instrument using Product Moment's expression and reliability test using Alpha Cronbach's. Hypothesis test consists of simple regression test and multiple regression test. The results showed that: (1) there was a positive relationship between Quality of Service to Satisfaction Society with $r x 1 y=0,594 ; r^{2} x 1 y=0.353$; $t$ count $(8,196)>t$ table $(1,979)$ at $5 \%$ significance level. (2) positive condition between Work Discipline to Satisfaction of Society with $r x 2 y=0,59 ; r^{2} x 2 y=0.359$; $t$ arithmetic (8.298)> t table (1.979) at a significance level of 5\%. (3). Conditions and Discipline Against Satisfaction of Society with $R y(1,2)=(0,671) ; R^{2} y(1,2)=(0,450) F$ value count $(49,989)>F$ table $(3,07)$ at $5 \%$ significance level.
\end{abstract}

Keywords: Service Quality, Work Discipline, Public Satisfaction.

\section{PENDAHULUAN}

Sebuah Organisasi Merupakan suatu wadah atau tempat yang digunakan beberapa orang untuk melakukan kerja sama. Organisai akan berkembang dengan sangat baik tergantung pada sumber daya yang tersedia, baik sumber daya manusia maupun sumber daya yang lain.

Sumber daya manusia sangat di butuhkan dalam suatu organisai pemerintah maupun swasta dalam aktifitas pelayanan. Dalam organisai pemerintah pelayanan yang baiak tercermin dari setiap efektivitas dan efesiensi kegiatan yang dilakukan. Semakin cepat dan akurat pelayanan yang diberikan maka kualitas pelayanan akan semakin baik. Semakin baik pelayanan yang diberikan akan mempengaruhi tingkat kepuasan yang dirasakan masyarakat sehingga pelayanan tersebut akan dinilai semakin bermutu.

Penegakan kedisiplinan pegawai, merupakan suatu yang penting bagi kualitas pelayanan, sebab kedisiplinan membuat pekerjaan yang dilakukan semakin efektif dan. Disiplin dapat meningkatkan kualitas organisai dan menghasilkan sesuatu dengan kebutuhan masyarakat.

Kepuasan dan ketidak puasan masyarakat merupakan bagian dari pengalaman masuatakay terhadap pelayanan dan disiplin kerja pegawai yang di peroleh. Berdasarkan pengalaman yang diperolehnya masyarakat memiliki kecendrungan untuk membangun nilai nilai ekspektasi tertentu. Nilai kepentasi tersebut akan memberikan dampak magi masyarakat untuk melakukan perbandingan terhadap organisai tersebut.secara langsung penilaian tersebut akan mempengaruhi pandangan dan penilaian masyarakat terhadap organisai.

Definisi mengenai pengertian pelayanan yang simpel diberikan oleh Invancevich, dkk dalam (Ratminto, 2015)" Pelayanan adalah produk-produk yang tidak kasat maya yang melibatkan usaha-usaha manusia menggunakan peralatan". Sedangkan definisi yang lebih rinci lagi diberikan oleh Goonroos dalam 
(Ratminto, 2015) " pelayanan adalah aktivitas atau serangkaian aktivitas yang bersifat tidak kasat mata yang terjadi sebagai akibat adanya interaksi anatar konsumen dan karyawan atau hal-hal lain yang disediakan oleh perusahaan pemberiu pelayana yang dimaksudkan untuk permasalahan konsumen atau pelanggan.

Karakteristika pleyanan menurut Suyono dalam (Nurhadi, 2017) mengemukakan bahwa jasa atau layanan dapat dibedakan menjadi empat yaitu:

1. Tidak berwujud: pelayanan atau jasa mempunyai sifat tidak berwujud karena tidak bisa di lihat, diraba, didengar atau dicium sebelum ada interaksi pembelian, agar kepercayaan konsumen dapat ditingkatkan ada beberapa hal yang perlu diperhatikan yaitu: meningkatkan visualisai pelayanan, memberi pelaynan tidak haya menggambarkan ciri-ciri suatu pelayanan tetapi lebih meningkatkan manfaat dari jasa tersebut, penataan fisik pelayaan yang cepat dan efisien dan menimbulkan kesan yang berish dan rapih, penataan dokumentasi harus dilakukan dengan rapih terjamin keamanananya dan efisien

2. Tidak dapat di pisahkan: pelayanan tidak bisa dipisahkan dari sumbernya, apabila sumber tersebut merupakan orang atau mesin sehingga produk fisik yang berwujud tetep ada

3. Heterogenitas: standarisai output setiap unit jasa itu berbeda satu sama lain

4. Cepat hilang dan peminatan yang fluktuasi: pelayanan cepet hilang tidka bisa di simpan dan berubah-ubah menurut musim, jam, dan hari.

Dimensi pelayanan menurut Parasuraman, et al dalam (Tjiptono, 2014) mengidentifikasi 10 dimensi pokok pleayanan yaitu:

1. Realibilitas mencakup dua aspek utama kinerja dan sifat terpercaya

2. Responsivitas atau daya tanggap

3. Kompetensi

4. Akses

5. Kesopanan

6. Komunikasi

7. Kreadibilitas

8. Keamanan

9. Bukti fisik

10. Kemampuan memahami pelanggan

Kualitas pelayanan menurut (Tjiptono, 2014) definisi kualitas pelayanan berfokus pada upaya memenuhan kebutuhan dan keinginan konsumen serta ketepatan penyampaian untuk mengimbangi harapan konsumen.
Sedangkan menurut Wyok yang dikutip oleh (Tjiptono, 2014) kualitas pelayanan merupakan tingkat keunggulan yang diharapkan dan pengendalian atas keunggulan tersebut untuk memenuhi kebutuhan konsumen.

Dimensi kualitas pelayanan menurut Tjiptono dalam Putri \& Arry (2016) adapun lima dimensi tersebut adalah:

1. Dimensi tampilan fisik : meliputi Fasilitas fisik, perlengkapan pegawai dan saran komunikasi

2. Dimensi keandalan: dalam bentuk kemampuan memberikan layanan yang di janjikan dengan segera, keakuratan dan memuaskan

3. Dimensi daya tanggap: keinginan para staf untuk membantu para konsumen dan membarikan pelayanan dengan tanggap

4. Dimensi jaminan mencakup pengetahuan, kemapuan, kesopanan dan sifat yang dipercaya yang memiliki para staf, bebas dari bahaya, resiko atau keragu-raguan

5. Dimensi empati meliputi kemudahan dalam melakukan hubungan komunikasi yang baik, perhatian pribadi dan memahami kebutuhan para konsumen

Disiplin kerja menurut Singodimegjo dalam (Sutrisno, 2017) menyatakan bahwa disiplin kerja adalah sikap kesediaan dan kerelaan seorang untuk mematuhi dan menaatai norma-norma peraturan yang berlaku di sekitarnya.

Sedangkan menurut (Sutrisno, 2017) menyatakan bahwa disiplin kerja adalah sikap kesediaan dan kerelaan seseorang untuk mematuhi dan mentaati norma-norma peraturan yang berlaku di sekitarnya.

Disiplain kerja mneurut Simamora dalam (Safudin, 2017) adalah bentuk pengendalian diri pegawai dan pelaksanaan yang teratur menunjukan tingkat kesungguhan tim kerja dalam organisai.

Faktor yang mempengaruhi disiplin kerja menurut Singodimedjo dalam (Sutrisno, 2017) adalah:

1. Besarkecilnya pemberian kompensasi

2. Ada tidaknya keteladanan pemimpin dalam perusahaan

3. Ada tidaknya aturan pasti yang dijadikan pegangan

4. Keberanian pemimpin dalam mengambil tindakan

5. Ada tidaknya pengawasan pimpinan

6. Ada tidaknya perhatian kepada karyawan

7. Diciptakan kebiasaan-kebiasaan yang mendukung tegaknya disiplin 
Indikator yang mempengaruhi kedisiplinan menurut hasibuan dalam (Irawan, 2018) adalah
1. Tujuan dan kemampuan
2. Teladan pemimpin
3. Balas jasa
4. Keadilan
5. Waskat (pengawasan melekat)
6. Sanksi hukuman
7. Ketegasan
8. Hubungan kemanusiaan

Kepuasan pelanggan menurut Kotler dalam (Atmaja, 2018) kepuasan pelanggan adalah perasaan senang atau kecewa seorang yang muncul setelah membandingkan antara kinerja (hasil) produk yang diperlukan terhadap kinerja yang diharapkan. Sedangkan menurut (Rangkuti, 2013.) kepuasan pelanggan adalah evaluasi pasca pembelian dimana alternnativ yang dibeli minimal sama atau melebihi harapan pelanggan.

Menurut Tjiptono dalam Majid (2013) kepuasan pelanggan atau ketidak puasan pelanggan adalah respon pelanggan terhadap evaluasi ketidak sesuaian atau konfirmasi yang dirasakan anatara harapan sebelumnya dan kinerja aktual produk yang dirasakan pemakainya. Faktor yang mempengaruhi kepuasan konsumen menurut Lupoyoadi dalam (Atmaja, 2018) antara lain:

1. Kualitas produk,

2. Kualitas pelayanan atau jasa

3. Emosi

4. Harga

5. Biaya

\section{METODOLOGI PENELITIAN}

Metode penelitian yang digunakan dalam penelitian ini adalah deskriftif kuantitatif dengan metide pengambilan data dengan metode kuesioner yang disebar sebayak 125 kuesioner yang diberikan kepada masyarakat yang datang kekantor lurah Klender selama satu bulan. Penelitian ini menggunakan skala liket dan korelasi untuk pengolahan data. Product Moment yang terdiri dari uji korelasi, uji determinasi, uji regresi sederhana, uji regresi ganda, uji t dan uji f.

\section{A. Variabel dan teknik pengukuran}

\section{Kepuasan Masyarata}

Definisi variabel kepuasan adalah skor total dari kuesioner kepuasan masyarakat yang meliputi kesesuaian harapan, persepsi kinerja, pelinaian Masyarakat. Terdiri dari 12 butir pertanyaan. Berikut kisi-kisi isntrumen penelitian variabel dependen yaitu kepuasan masyarakat sebagai berikut.
Tabel 1 kisi-kisi instrumen penelitian variabel kepuasan masyarakat

\begin{tabular}{lll}
\hline Variabel & Dimensi & Indikator \\
\hline Kepuasan & $\begin{array}{l}\text { Kesesuaian } \\
\text { harapan }\end{array}$ & $\begin{array}{l}\text { Sesuai } \\
\text { kebutuhan dan } \\
\text { cepat serta } \\
\text { tepat }\end{array}$ \\
& Persepsi kinerja & $\begin{array}{l}\text { Kinerja, } \\
\text { informasi, } \\
\text { kemudahan, } \\
\end{array}$ \\
& nyaman dan \\
& keamanan \\
& Kinerja lebih \\
& penilaian & berpengetahuan \\
& luas, \\
& memberikan \\
& informasi dan \\
& menerapkan 3S \\
& (seyum, sapa, \\
& salam)
\end{tabular}

Sumber: Consuegra dalam (Savitri, 2017)

Variabel kepuasan masyarakat dalam penelitian ini akan di ukut menggunakan skala liket dengan lima pilihan yaitu SS (sangat setuju), S (setuju), N(netral), TS (tidak setuju) dan STS (sangat tidak setuju) pilihan di beri nilai dnegan pembobotan seperti tertera pada tabel dibawah ini

Tabel 2 Daftar Pembobotan Penilaian kepuasan

\begin{tabular}{lll}
\multicolumn{2}{c}{ Masyarakat } \\
\hline No & Arternatif jawaban & Bobot nilai \\
\hline $\mathbf{1}$ & SS (sangat setuju) & 5 \\
$\mathbf{2}$ & S (setuju) & 4 \\
$\mathbf{3}$ & N (netral) & 3 \\
$\mathbf{4}$ & TS(tidak setuju) & 2 \\
$\mathbf{5}$ & STS( sangat tidak setuju) & 1 \\
\hline
\end{tabular}

Sumber: (Sugiyono, 2016)

\section{Kualitas pelayanan}

Definisi kualitas pelayanan adalah skor total dairi kuesioner kualitas pelyanan yang meliput Bukti fisik, keandalan, ketanggapan, jaminan, empati. Terdiri dari 8 butir pertanyaan. Berikut kisi-kisi instrumen penelitian variabel independen yaitu kualitas pelayanan sebagai berikut: 
Tabel 3 Kisi-kisi Instrumen Penelitian Variabel Kualitas pelayanan

\begin{tabular}{|c|c|c|}
\hline Variabel & Dimensi & Indikator \\
\hline \multirow[t]{5}{*}{$\begin{array}{l}\text { Kualitas } \\
\text { Pelayanan }\end{array}$} & Bukti Fisik & $\begin{array}{l}\text { Fasilitas fisik, } \\
\text { Perlengakpan } \\
\text { pegawai, dan } \\
\text { sarana } \\
\text { komunikasi }\end{array}$ \\
\hline & Keandalan & $\begin{array}{l}\text { Kecepatan, } \\
\text { kekauratan dan } \\
\text { memuaskan }\end{array}$ \\
\hline & Ketanggapan & $\begin{array}{l}\text { Ketanggapan } \\
\text { karyawan dan } \\
\text { memberi } \\
\text { pelayanan } \\
\text { dengan tanggap }\end{array}$ \\
\hline & Jamianan & $\begin{array}{l}\text { Pengetahuan, } \\
\text { kemampuan } \\
\text { dan kesopanan }\end{array}$ \\
\hline & Eampati & $\begin{array}{l}\text { Perhatian dan } \\
\text { komunikasi } \\
\text { yang baik }\end{array}$ \\
\hline
\end{tabular}

Sumber: Singodimedjo dalam (Sutrisno, 2017)

Variabel kualitas pelayanan dalam penelitian ini akan diukur menggunakan Skala Liket dengan Lima pilihan yaitu SS (sangat setuju), S (setuju), N(netral), TS (tidak setuju) dan STS (sangat tidak setuju) pilihan di beri nilai dnegan pembobotan seperti tertera pada tabel dibawah ini.

Tabel 4 Daftar Pembobotan Penilaian Kualitas pelayanan

\begin{tabular}{lll}
\hline No & Arternatif jawaban & Bobot nilai \\
\hline $\mathbf{1}$ & SS (sangat setuju) & 5 \\
$\mathbf{2}$ & S (setuju) & 4 \\
$\mathbf{3}$ & N (netral) & 3 \\
$\mathbf{4}$ & TS(tidak setuju) & 2 \\
$\mathbf{5}$ & STS( sangat tidak setuju) & 1 \\
\hline
\end{tabular}

Sumber: (Sugiyono, 2016)

\section{Disiplin Kerja}

Definisi Disiplin Kerja adalah skor total dari kuesioner disiplin kerja yang meliputi Taat Terhadap waktu, taat terhadap peraturan perusahaan, taat terhadap aturan prilaku dalam pekerjaan. Terdiri dari 8 butir pertanyaan. Berikut kisi-kisi intrumen penelitian variabel independen yaitu disiplin kerja sebagai berikut.
Tabel 5 Kisi-kisi isntumen penelitian variabel Disiplin Kerja

\begin{tabular}{|c|c|c|}
\hline variabel & Dimensi & Indikator \\
\hline \multirow[t]{3}{*}{$\begin{array}{l}\text { Disiplin } \\
\text { Kerja }\end{array}$} & $\begin{array}{l}\text { Taat terhadap } \\
\text { waktu }\end{array}$ & $\begin{array}{l}\text { Jam masuk kerja, } \\
\text { jam pulang dan jam } \\
\text { istirahat }\end{array}$ \\
\hline & $\begin{array}{l}\text { Taat terhadap } \\
\text { peraturan } \\
\text { perusahaan }\end{array}$ & $\begin{array}{l}\text { Berpakaian dan } \\
\text { bertingkah laku }\end{array}$ \\
\hline & $\begin{array}{l}\text { Taat terhadap } \\
\text { aturan } \\
\text { prilaku } \\
\text { dalam } \\
\text { pekerjaan }\end{array}$ & $\begin{array}{l}\text { Pekerjaan sesuai } \\
\text { jabatan, tugas, dan } \\
\text { tanggung jawab }\end{array}$ \\
\hline
\end{tabular}

Sumber: Singodimenjo dalam (Sutrisno, 2017)

Variabel Disiplin Kerja dalam penelitian ini akan diukur menggunakan Skala Liket dengan Lima pilihan yaitu SS (sangat setuju), S (setuju), N(netral), TS (tidak setuju) dan STS (sangat tidak setuju) pilihan di beri nilai dnegan pembobotan seperti tertera pada tabel dibawah ini.

Tabel 6. Daftar Pembobotan Penilaian Disiplin Kerja

\begin{tabular}{lll}
\hline No & Arternatif jawaban & Bobot nilai \\
\hline $\mathbf{1}$ & SS (sangat setuju) & 5 \\
$\mathbf{2}$ & S (setuju) & 4 \\
$\mathbf{3}$ & N (netral) & 3 \\
$\mathbf{4}$ & TS(tidak setuju) & 2 \\
$\mathbf{5}$ & STS( sangat tidak setuju) & 1 \\
\hline
\end{tabular}

Sumber: (Sugiyono, 2016)

\section{B. Cara Pengolahan Data dan Pngujian Hipotesisi \\ 1. Uji Kualitas data}

Untuk mencapai tujuan penelitian sesuai dengan yang diharapkan dalam penelitian ini dna untuk mendapatkan kesimpulan maka data yang telah terkumpul merupakan gambaran dari variabel yang diteliti dan berfungsi sebagai alat pembuktian hipotesiss. Kualitas data tergantung dari baik tidaknya instrumen pengumpulan data. Sehingga harus dilakukan uji kualitas data yang pada dasarnya merupakan pengujian terhadap isntumen pengumpulan data yaitu uji validitas dan realibilitas.

\section{a. Uji Validitas}

Menurut (Echdar, 2017) uji validitas dilakukan untuk memastikan seberapa baik suatu instrumen digunakan untuk mengukur konsep yang seharusnya diukur. Metode yang sering digunakan untuk memberikan penilaian terhadap validitas kuesioner adalah korelasi product Moment antara skor total sehingga sering di sebut sebagai inter item total correlation. Nilai korelasi yang di peroleh lalu 
dibandingkan dengan tabel nilai korelasi (r) product moment. Jika $r_{\text {hitung }}>\mathrm{r}_{\text {Tabel }}$ pada taraf kepercayaan tertentu $(5 \%)$ berati instrumen memenuhi kriteria validitas. Namun apabila $r_{\text {Hitung }}<r_{\text {Tabel }}$ maka butir instrumen tidak valid. Perhitungan validitas menggunakan bantuan program SPSS 23 for windows

\section{b. Uji Reliabilitas}

Menurut (Suharsimi, 2010) reliabilitas menunjukan pada suatu pengertian bahwa suatu isntrumen cukup dapat dipercaya untuk digunakan sebagai alat pengumpulan data karena instrumen tersebut sudah baik. Sednagkan menurut Sukmadinata dalam (Echdar, 2017) reliabilitas berkenaan dengan tingkat ketepatan hasil pengukuran. Kuesioner dikatakan reliabel jika dapat memberikan hasil relatif sama pada saat dilakukan pengukuran kembali pada objek yang berjalan pada waktu yang berbeda atau memberikan hasil yang tepat. Dalam uji reliabilitas penelitian ini menggunakan aplikasi SPSS 23 for windows. Hasil perhitungan kemudian di interpretasikan untuk mengetahui apakah suatu intrumen reliabel atau tidak dengan menggunakan pedoman yang dapat dilihat pada tabel berikut

Tabel 7 Skala Alpha Cronbach's

\begin{tabular}{ll}
\hline Nilai Alpha & Keterangan \\
\hline $\mathbf{0 , 0 - 0 , 2 0}$ & Kurang reliabel \\
$\mathbf{0 , 2 1 - 0 , 4 0}$ & Agak reliabel \\
$\mathbf{0 , 4 1 - 0 , 6 0}$ & Cukup reliabel \\
$\mathbf{0 , 6 1 - 0 , 8 0}$ & Reliabel \\
$\mathbf{0 , 8 1 - 1 . 0 0}$ & Sangat reliabel \\
\hline
\end{tabular}

Sumber: Sujianto dalam (Widiyanti, 2017)

Instrumen dikatakan reliabel jika $\mathrm{r}_{\text {Hitunglebih besar }}$ atau sama dengan $r_{\text {Tabel }}$ instrumen dikatakan reliabel atau $r_{\text {Hitung }}$ dikonsultasikan dnegan tabel interpretasi $\mathrm{r}$ dengan ketentuan dikatakan reliabel jika $\mathrm{r}_{\text {hitung }}$ $\geq 0.600$. Uji reliabilitas menggunakan bantuan program SPSS 23 for windows.

\section{Uji Hipotesisi}

Ada beberapa asumsi yang terlebih dahulu harus dipenuhi sebelum menggunakan metode multipel linear Regression sebagai alat statistik untuk menganalisis pengaruh variabel-variabel yang diteliti. Uji asumsi klasik dengan sofwer SPSS 23 yang dilakukan dalam penelitian ini adalah sebagai berikut.

\section{a. Koefisien korelasi}

Menurut (Sugiyono, 2016) jika data yang akan dikorelasikan berbentuk interval dan dari sumber data yang sama, untuk itu teknik korelasi yang digunakan adalah pearson product moment. Teknik ini digunakan untuk memberikan interpretasi terhadap kuatnya hubungan variabel yaitu antara variabel kualitas pelayanan terhadap kepuasan masyarakat dan disiplin kerja terhadap kepuasan masyarakat.

Uji koefisien menggunakan bantuan program SPSS 23 for windows. Sednagkan koefisien korelasi ganda menurut (Sugiyono, 2016) digunakan untuk memebrikan interpretasi terhadap kuatnya hubungan dua variabel X1 dan X2 secara bersama-sama terhadap variabel $Y$, yaitu variabel kualitas pelayanan dan disiplin kerja terhadap kepuasan Masyarakat. Uji koefisien korelasi ganda menggunakan bantuan program SPSS 23 for windows, untuk mengetahu tingkat hubungan anatar variabel dapat diketahui smenggunakan tabel pedoman yang diuraikan sebagai berikut:

Tabel 8 pedoman untuk memberikan interpretasi koefisien korelasi

\begin{tabular}{ll}
\hline Interval koefisien & Tingkat hubungan \\
\hline $\mathbf{0 , 0 0}-\mathbf{0 , 1 9 9}$ & Sangat rendah \\
$\mathbf{0 , 2 0}-\mathbf{0 , 3 9 9}$ & Rendah \\
$\mathbf{0 , 4 0}-\mathbf{0 , 5 9 9}$ & Sedang \\
$\mathbf{0 , 6 0}-\mathbf{0 , 7 9 9}$ & Kuat \\
$\mathbf{0 , 8 0}-\mathbf{1 , 0 0 0}$ & Sangat Kuat \\
\hline
\end{tabular}

Sumber: (Sugiyono, 2016)

\section{b. Koefisien Determinasi}

Menurut (Pardede, 2014) koefisien determinasi dinotasikan dengan $\mathrm{R}^{2}$ merupakan suatu ukuran yang penting dalam regresi, karena dapat menginformasikan baik atau tidaknya model regresi yang terestimasi. Atau dengan kata lain angka tersebut dapat mengukur seberapa dekatkah garis regresi yang terestimasi dengan data sesungguhnya. Uji koefisien determinasi menggunakan bantuan program SPSS 23 for windows.

\section{c. Persamaan regresi sederhana}

Menurut (Sugiyono, 2016) regresi sederhana disasarkan pada hubungan fingsional ataupun kausal satu variabel independen dengan satu variabel devenden. Uji persamaan regresi sederhana menggunakan bantuan program SPSS 23 for windows.

\section{d. Persamaan Regresi Berganda}

Menurut (Sutrisno, 2017)regresi ganda digunakan oleh peneliti apabila peneliti bermaksud mengetahui bagaimana keadaan variabel dependen, bila dua atau lebih variabel indevenden sebagai faktor predictor dimanipulasi. Jadi regresi ganda dilakukan apabila jumlah variabel independennya minimal 2 . Uji persamaan regresi berganda menggunakan 
bantuan program SPSS 23 for windows

\section{e. Uji T}

Menurut (Sugiyono, 2016) uji t dilakukan untuk menguji signifikasi suatu variabel $\mathrm{X}$ terhadap $\mathrm{Y}$ berlaku untuk semua populasi, maka perlu diuji signifikansinya. Uji t menggunakan bantuan program SPSS 23 for windows.

\section{f. Uji F}

Menurut (Sugiyono, 2016) dilakukan untuk menguji signifikansi suatu variabel $\mathrm{X} 1$ dan $\mathrm{X} 2$ terhadap $\mathrm{Y}$ berlaku untuk semua populasi. Uji $\mathrm{F}$ menggunakan bantuan program SPSS 23 for windows.

\section{HASIL DAN PEMBAHASAN}

\section{A. Karakteristik Responden}

Penelitian ini dilakukan untuk mengetahui pengaruh kualitas pelayanana dan disiplin kerja terhadap kepuasan masyarakat pada kantor Lurah Kelurahan Klender. Dari hasil penelitian dapat diketahui gambaran karakteristik responden yang meliputi jenis kelamin, usia, pekerjaan.Deskripsi karakteristik responden berdasarkan Jenis kelamin disajikan pada gambar dibawah ini

Tabel 9 karakteristik responden berdasarkan jenis kelamin

\begin{tabular}{llll}
\hline No & Jenis Kelamin & Jumlah & \\
\hline & & Orang & Persentasi \\
$\mathbf{1}$ & Laki-laki & 66 & $53 \%$ \\
2 & Perempuan & 59 & $47 \%$ \\
& Jumlah & 125 & $100 \%$ \\
\hline
\end{tabular}

Sumber:Data primer yang diolah penulis (2018)

Dari tabel diatas menunjukan dari 125 responden sebayak 66 responden yang melakukan pengisian kuesioner sebagaian besar berjenis kelamin laki-laki yaitu sebesar 53\% dalam bentuk angka sebanyak 66 orang. Sednagkan perempuan sebesar $74 \%$ dalam bentuk angka sebanyak 59 orang.

Deskripsi karakteristik responden berdasarkan usia disajikan pada gambar dibawah ini.

Tabel 10 karakteristik responden berdasarkan Usia

\begin{tabular}{llll}
\hline No & Tingkat Usia & Jumlah & \\
\hline & & Orang & Persentasi \\
$\mathbf{1}$ & $17-28$ & 53 & $42 \%$ \\
$\mathbf{2}$ & $29-39$ & 41 & $33 \%$ \\
$\mathbf{3}$ & $>40$ & 31 & $25 \%$ \\
& Jumlah & 125 & $100 \%$ \\
\hline
\end{tabular}

Sumber: data primer yang dioleh penulis (2018)
Dari tabel diatas menunjukan dari 125 responden di dominasi oleh usia 17-28 tahun sebanyak $42 \%$ atau dalam bentuk angka sebanyak 53 orang. Sednagkan sebanyak 33\% disi oleh usia 29-39 tahun atau dalam bentuk angka sebnayak 41 orang, dan persentasi untuk usia $>40$ tahun sebanyak $25 \%$ atau dalam bentuk angka sebanyak 31 orang.

Deskripsi karakteristik responden berdasarkan pekerjaan disajikan pada gambar dibawah ini.

Tabel 11 karakteristik responden berdsarkan pekerjaan

\begin{tabular}{llll}
\hline No & Jenis pekerjaan & Jumlah & \\
\hline & & Orang & Persentasi \\
$\mathbf{1}$ & Karyawan Swata & 48 & $38 \%$ \\
$\mathbf{2}$ & Pelajar/mahsiswa & 30 & $24 \%$ \\
$\mathbf{3}$ & Ibu Rumah tangga & 25 & $20 \%$ \\
$\mathbf{4}$ & Wiraswasta & 16 & $13 \%$ \\
$\mathbf{5}$ & Pegawai Negeri & 6 & $5 \%$ \\
& Jumlah & 125 & $100 \%$
\end{tabular}

Sumber: data primer yang dioleh penulis (2018)

Dari tabel diatas sebanyak $38 \%$ memiliki pekerjaan sebagai karyawna swasta atau dalam bentuk angka sebanyak 48 orang, 24\% terdiri dari pelajar/ mahasiswa atau dalam bentuk angka sebanyak 30 orang, 20\% terdiri dari ibu rumah tangga atau tidak bekerja yang dalam bentuk angka sebanyak 25 orang, lalu $13 \%$ wiraswasta yang dalam bentuk angka sebanyak 16 orang, dan yang terakhir $5 \%$ pegawai negeri yang dalam bentuk angka sebanyak 6 orang.

\section{B. Uji Validitas dan Reliabilitas Instrumen 1. Uji Validitas}

Dalam penelitian ini penulis memiliki sempel sebanyak 125 responden. Pengujian dilakukan dengan membandingkan $r_{\text {Hitung dengan }} r_{\text {Tabel }}$. Nilai $r_{\text {Hitung }}$ merupakan hasil korelasi jawaban responden pada masing-masing pertanyaan disetiap variabel yang dianalisi dengan SPSS 23 for windows. Besarnya $r$ tabel dengan taraf signifikasi $5 \%$ adalah 0,176 bisa dilihat pada tabel 10 berikut ini.

Tabel 10 hasil validitas

\begin{tabular}{lllll}
\hline $\begin{array}{l}\text { Variab } \\
\text { el }\end{array}$ & Indikator & rhitung & $\mathbf{r}_{\text {tabel }}$ & $\begin{array}{l}\text { Ketera } \\
\text { ngan }\end{array}$ \\
\hline & $\begin{array}{l}\text { kualitas } \\
\text { pelayanan1 } \\
\text { Kualitas } \\
\text { pelayanan2 } \\
\text { kualitas } \\
\text { pelayanan3 } \\
\text { kualitas } \\
\text { pelayanan4 }\end{array}$ & 0,395 & 0,404 & VALID \\
& 0,506 & VALID \\
& & VALID \\
& & VALID \\
\hline
\end{tabular}




\begin{tabular}{|c|c|c|c|c|}
\hline \multirow{2}{*}{$\begin{array}{l}\text { Kualita } \\
\text { s } \\
\text { pelaya }\end{array}$} & $\begin{array}{l}\text { kualitas } \\
\text { pelayanan5 }\end{array}$ & 0,672 & 0,176 & VALID \\
\hline & $\begin{array}{l}\text { kualitas } \\
\text { pelayanan6 }\end{array}$ & 0,509 & & VALID \\
\hline \multirow{7}{*}{$\begin{array}{l}\text { nan } \\
\left.X^{1}\right)\end{array}$} & kualitas & 0,733 & & VALID \\
\hline & pelayanan7 & & & \\
\hline & $\begin{array}{l}\text { kualitas } \\
\text { pelayanan8 }\end{array}$ & 0,699 & & VALID \\
\hline & Disiplin & 0,697 & & VALID \\
\hline & kerja 1 & & & \\
\hline & Disiplin & 0,462 & & VALID \\
\hline & kerja 2 & & & \\
\hline \multirow{18}{*}{$\begin{array}{l}\text { Disipli } \\
\text { n } \\
\text { Kerja } \\
\left(\mathbf{X}^{2}\right)\end{array}$} & Disiplin & 0,637 & 0,176 & VALID \\
\hline & kerja 3 & & & \\
\hline & Disiplin & 0,504 & & VALID \\
\hline & kerja 4 & & & \\
\hline & Disiplin & 0,396 & & VALID \\
\hline & kerja 5 & & & \\
\hline & Disiplin & 0,584 & & VALID \\
\hline & kerja 6 & & & \\
\hline & Disiplin & 0,439 & & VALID \\
\hline & kerja 7 & & & \\
\hline & Disiplin & 0,520 & & VALID \\
\hline & kerja 8 & & & \\
\hline & Kepuasan & 0,486 & & VALID \\
\hline & masyarakat & & & \\
\hline & Kepuasan & 0,532 & & VALID \\
\hline & $\begin{array}{l}\text { masyarakat } \\
2\end{array}$ & & & \\
\hline & Kepuasan & 0,410 & & VALID \\
\hline & masyarakat & & & \\
\hline \multirow{22}{*}{$\begin{array}{l}\text { Kepuas } \\
\text { an } \\
\text { Masya } \\
\text { rakat } \\
\text { (Y) }\end{array}$} & 3 & & & \\
\hline & Kepuasan & 0,368 & 0,176 & VALID \\
\hline & $\begin{array}{l}\text { masyarakat } \\
4\end{array}$ & & & \\
\hline & Kepuasan & 0,566 & & VALID \\
\hline & $\begin{array}{l}\text { masyarakat } \\
5\end{array}$ & & & \\
\hline & Kepuasan & 0,579 & & VALID \\
\hline & masyarakat & & & \\
\hline & 6 & & & \\
\hline & $\begin{array}{l}\text { Kepuasan } \\
\text { masyarakat }\end{array}$ & 0,439 & & VALID \\
\hline & 7 & & & \\
\hline & Kepuasan & 0,340 & & VALID \\
\hline & masyarakat & & & \\
\hline & Kepuasan & 0,413 & & VALID \\
\hline & $\begin{array}{l}\text { masyarakat } \\
9\end{array}$ & & & \\
\hline & Kepuasan & 0,626 & & VALID \\
\hline & masyarakat & & & \\
\hline & 10 & & & \\
\hline & Kepuasan & 0,513 & & VALID \\
\hline & masyarakat & & & \\
\hline & 11 & & & \\
\hline & Kepuasan & 0,323 & & VALID \\
\hline & $\begin{array}{l}\text { masyarakat } \\
12\end{array}$ & & & \\
\hline
\end{tabular}

Dari tabel diats menunjukan niali $r_{\text {hitung }}$ semua indikator lebih besar dari pada niali $r_{\text {tabel }}$ sehingga semua indikator dinyatakan Valid.

\section{Uji Reliabilitas}

Reliabilitas suatu kuesioner atau indikator dari perhitungan menggunakan apslikasi SPSS 23 for windosw dapat dilihat nilai Cronbach's Alpha, kemudian diinterpretasikan pada tabel skala Cronbach's Alpha . hasil reliabititas output aplikasi SPSS 23 bisa lilihat pada tabel berikut:

Tabel 12 hasil reliabilitas

\begin{tabular}{|c|c|c|c|}
\hline Variabel & Alpha & $\begin{array}{ll}\mathrm{r}_{\text {tabel }} & 5 \% \\
(125) & \\
\end{array}$ & Keterangan \\
\hline $\mathrm{X}_{1}$ & 0,696 & 0,176 & Reliabel \\
\hline $\mathrm{X}_{2}$ & 0,643 & 0,176 & Reliabel \\
\hline $\mathrm{Y}$ & 0,672 & 0,176 & Reliabel \\
\hline
\end{tabular}

Sumber: hasil olah data SPSS 23 (2018)

Dari tabel diatas menunjukan nilai Cronbach's Alpha semua variabel masuk dalam katagori reliabel, sehingga dapat disimpulkan indikator atau kuesioner yang digunakan dalam penelitian adalah handal atau dapat dipercaya sebagai alat ukur variabel.

\section{Uji persayarata Analisis}

1. Analisis Variabel $X_{1}$ Terhadap $Y$

Pengujian analisis Variabel $\mathrm{X}_{1}$ terhadap $\mathrm{Y}$ dilakukan dengan menggunakan teknik analisis regresi sederhana. Analisis ini menggunakan abantuan program SPSS 23 for windows. Hasil uji analisis Variabel $\mathrm{X}_{1}$ terhadap $\mathrm{Y}$ dapat dilihat pada tebel berikut.

Tabel 13 Ringkasan Hasil Analisis Regresi Linear Sederhana $\mathrm{X}_{1}-\mathrm{Y}$

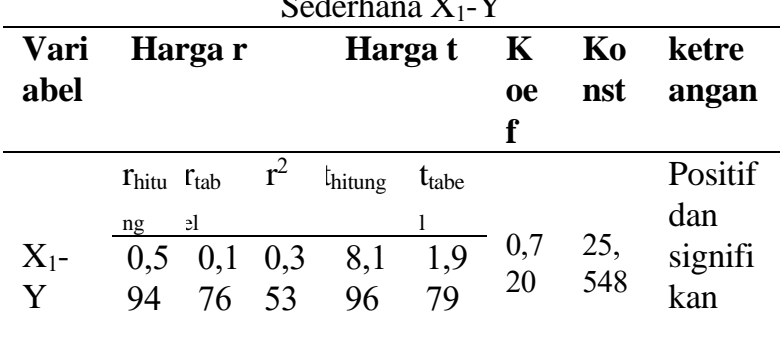

Sumber: data Hasil olah data SPSS 23 (2018)

Berdasarkan tabel 13 hasil analsiis regresi linear sederhana variabel $\mathrm{X}_{1}$ terhadap variabel $\mathrm{Y}$ sebagai berikut.

\section{a. Uji koefisien korelasi}

Berdasarkan perhitungan menggunakan bantuan program SPSS 23 for windows, menunjukan bahwa koefisien korelasi ( $\mathrm{r}_{\text {hitung }}$ ) anatar $\mathrm{X}_{1}$ terhadap $\mathrm{Y}\left(\mathrm{r}_{\mathrm{X} 1 \mathrm{Y}}\right)$ sebesar 0,594 karena koefisien korelasi $\mathrm{r}_{\mathrm{X} 1 \mathrm{Y}}$ tersebut 
bernilai positif, maka kualitas pelayanan berpengaruh positif terhadap kepuasna masyarakat dan dapat disimpulkan bahwa semakin tinggi kualitas pelayanan maka kepuasan masyarakat juga semakin tinggi.

\section{b. Uji koefisien determinasi}

Berdasarkan perhitungan menggunakan program SPSS 23 yang dapat dilihat pada tebl 13 diatas, diperoleh koefisisne determinasi $\left(\mathrm{r}^{2} \mathrm{X1Y}\right)$ sebesar 0,353 . Nilai $\mathrm{r}^{2} \mathrm{X} 1 \mathrm{Y}$ dapat diartikan bahwa kualitas pelayanan mampu mempengaruhi sebesar $35 \%$ perubahan kepuasan masyarakat

\section{c. Uji T}

Uji $\mathrm{T}$ bertujuan untuk mengetahui signifikansi kualitas pelayanan terhadap kepuasan masyarakat. Pengaruh signifikansi hipotesisi penelitian diketahui dnegan uji T. Apabila thitung lebih besar dari $t_{\text {tabel }}$ maka variabel bebas memiliki pengaruh yang signifikan terhadap variabel terikat. Berdasarkan hasil pengujian dengan program bantuan SPSS 23 diketahui thitung sebesar 8,196 dan diketahui $t_{\text {tabel }}$ sebesar 1,979. Dengan demikian thitung lebih besar daripada tabel yaitu $8,196>1,979$ berdasrkan perhitungan tersebut dapat disimpulkan bahwa kualitas pelayanan berpengaruh signifikan terhadap kepuasan masyarakat.

\section{d. Uji persamaan regresi}

Besar harga koefisien kualitas pelayanan sebesar 0,720 dan bilanagan konstanta 25,548. Berdasrakan angka tersebut, maka dapat disusun persamaan regresi sebagai berikut

$$
\mathrm{Y}=0,720 \mathrm{X}_{1}+25,548
$$

Persamaan tersebut menunjukan bahwa nilai kiefisien $\mathrm{X}_{1}$ sebesar 0,720 artuya apabila kualitas pelyanan meningkat 1 point maka kepuasan masyarakat meningkat 0,720

\section{Analisis Variabel $X_{2}$ terhadap $Y$}

Pengujian analisis variabel $\mathrm{X}_{2}$ terhadap $\mathrm{Y}$ dilakukan dengan menggunakan teknik analisisi regresi sederhana . analisis ini menggunakan bantuan program SPSS 23 for windows hasil uji analisis variabel $\mathrm{X}_{2}$ terhadap $\mathrm{Y}$ dapat dilihat pada tebel 14 .

Tabel 14 Ringkasan Hasil Analisis Rehresi Linier Sederhana $\mathrm{X}_{2}-\mathrm{Y}$

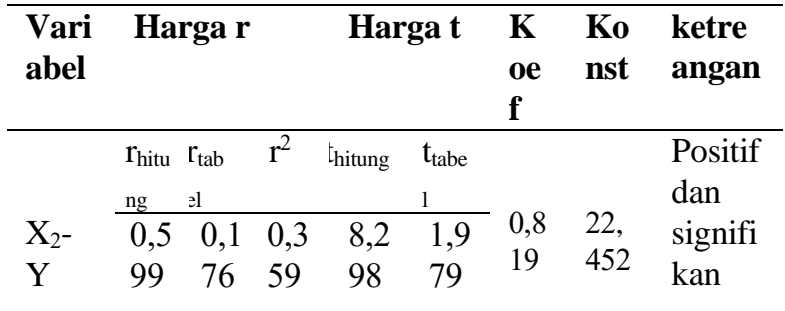

Sumber: Hasil Olah data SPSS 23 (2018)
Berdasarkan tabel 14 hasil analsiis regresi linear sederhana variabel $\mathrm{X}_{2}$ terhadap variabel $\mathrm{Y}$ sebagai berikut.

\section{a. Uji koefisien korelasi}

Berdasarkan perhitungan menggunakan bantuan program SPSS 23 for windows, menunjukan bahwa koefisien korelasi ( $\left.\mathrm{r}_{\text {hitung }}\right)$ antara $\mathrm{X}_{2}$ terhadap $\mathrm{Y}\left(\mathrm{r}_{\mathrm{X} 2 \mathrm{Y}}\right)$

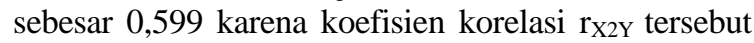
bernilai positif, maka disiplin kerja berpengaruh terhadap kepuasan masyarakat dan dapat disimpulkan bahwa semakin tinggi disiplin kerja $\left(\mathrm{X}_{2}\right)$ maka kepuasan masyarakat $(\mathrm{Y})$ juga semakin tinggi.

\section{b. Uji Koefisien Determinasi}

Berdasarkan perhitungan menggunakan bantuan program SPSS 23 koefisien determinasi $\left(\mathrm{r}^{2} \mathrm{X2Y}\right)$ sebesar 0,359. Nilai $\mathrm{r}^{2} \mathrm{X2Y}$ dapat diartikan bahwa disiplin kerja $\left(\mathrm{X}_{2}\right)$ memapu mempengaruhi sebesar $35,9 \%$ perubahan kepuasan masyarakat $(\mathrm{Y})$

\section{c. Uji t}

Uji t bertujuan untuk mengetahui signifikansi disiplin kerja terhadap kepuasna masyarakat. Apabila $t_{\text {hitung }}$ lebih besar dari $t_{\text {tabel }}$ maka variabel bebas memiliki pengaruh signifikasn terhadpa variabel terikat. Berdasarkan hasil pengujian dengan bantuan program SPSS 23 for windows diketahui thitung sebesar 8,298 dan diketahui tabel sebesar 1,979. Dengan demikin $t_{\text {hitung }}$ lebih besar dari pada $t_{\text {tabel }}$ yaitu 8,298>1,979. Berdasrkan perhitungan tersebut dapat disimpulkan bahwa disiplin kerja berpengaruh signifikan terhadap kepuasan masyarakat.

\section{d. Uji Persamaan Regresi}

Besarnya harga koefisien disiplin kerja $\left(\mathrm{X}_{2}\right)$ sebesra 0,819 dan bilangan konstanta sebesar 22,452. Berdasarkan angka tersebut, maka dapat disusun persamaan regresi sebagai berikut:

$$
\mathrm{Y}=0,819 \mathrm{X}_{2}+22,452
$$

Persamaan tersebut menunjukan bahwa nilai koefisien $\mathrm{X}_{2}$ sebesar 0,819 artinya apabila disiplin kerja meningkat 1 poin maka kepuasan masyarakat akan meningkat 0,819 .

\section{Analisis Variabel $X_{1}$ dan $X_{2}$ Terhadap $Y$}

Pengujian analisis variabel $\mathrm{X}_{1}$ dan $\mathrm{X}_{2}$ terhadap $\mathrm{Y}$ dilakukan dengan menggunakan teknik analsisi regresi ganda. Analisis menggunakan bantuan SPSS 23 for windows. Hasil uji dapat dilihat pada tabel berikut. 
Tabel 15 Ringkasan Hasil Analisis Regresi Ganda $\mathrm{X}_{1}$ dan $\mathrm{X}_{2}$ terhadap $\mathrm{Y}$

\begin{tabular}{|c|c|c|c|c|c|c|}
\hline $\begin{array}{c}\text { Varia } \\
\text { bel }\end{array}$ & Koef. 1 & $\begin{array}{l}\text { Kons } \\
\text { t. } \\
\end{array}$ & $\begin{array}{ll}\text { Harga } & R \\
\text { dan } R^{2} & \\
\end{array}$ & & $\operatorname{arga~F}$ & $\begin{array}{c}\text { Keteran } \\
\text { gan }\end{array}$ \\
\hline & & Ry & $\mathrm{y}\left(1, \mathrm{R}^{2} \mathrm{y}(1,2\right.$ & $\mathrm{F}$ & & Positif \\
\hline \multirow[t]{2}{*}{$\mathrm{X} 1$} & 0,451 & $17,2^{2)}$ & ) & hitung & F tabel & dan \\
\hline & & 74 & 0,6 & & & Signifi \\
\hline $\mathrm{X} 2$ & 0,524 & & $71 \quad 0,450$ & 49,989 & 3,07 & kan \\
\hline
\end{tabular}

Sumber: hasil olah data SPSS (2018)

Berdasrakan tabel 15 hasil analisis Regresi ganda variabel $\mathrm{X}_{1}$ dan $\mathrm{X}_{2}$ terhadap $\mathrm{Y}$ sebagai berikut.

\section{a. Uji koefisien korelasi}

Berdasarkan perhitungan dengan menggunakan program SPSS 23 For windows menunjukan bahwa koefisien korelasi antara $\mathrm{X}_{1}$ dan $\mathrm{X}_{2}$ terhadap $\mathrm{Y}$ $\left(r_{Y(1,2)}\right)$ sebesar 0,671. Karena koefisien korelasi $\left(r_{Y(1,2)}\right)$ bernilai positif, maka kualitas pelayanan dan disiplin kerja secara bersama-sama berpengaruh positif terhadap kepuasan masyarakat. Sehingga dapat disimpulkan bahwa jika terdapat peningkatan kualitas pelayanan dan disiplin kerja secara bersama-sama maka kepuasan masyarakat akan meningkat.

\section{b. Uji Koefisien Determinasi}

Koefisien Determinasi $\left(\mathrm{r}^{2} \mathrm{Y}(1,2)\right.$ ) sebesar 0,450 , berati bahwa kualitas pelayanan $\left(\mathrm{X}_{1}\right)$ dan disiplin kerja $\left(\mathrm{X}_{2}\right)$ mampu mempengaruhi $45 \%$ perubahan kepuasan masyarakat.

\section{c. Uji F}

Uji $F$ bertujuan untuk mengetahui signifikansi pengaruh kualitas pelayanan $\left(\mathrm{X}_{1}\right)$ dan disiplin kerja $\left(\mathrm{X}_{2}\right)$ secara bersama-sama terhadap kepuasan masyarakat (Y). Apabila $F_{\text {hitung }}$ lebih besar dari pada $F_{\text {tabel }}$ maka variabel bebas memiliki pengaruh sigbifikan terhadap fariabel terikat. Berdasarkan hasil uji $\mathrm{F}$ dapat diketahui $\mathrm{F}_{\text {hitung }}$ sebesar 49,989 dan $\mathrm{F}_{\text {tabel }}$ dengan taraf signifikan 5\% sebesar 3,07, maka $49.989>3,07$. Dengan nilai tersebut dapat diketahui $F_{\text {hitung }}>F_{\text {tabel }}$, sehingga terdapat pengaruh signifikan kualitas pelayanan $\left(\mathrm{X}_{1}\right)$ dan disiplin kerja $\left(\mathrm{X}_{2}\right)$ secara bersama-sama terhadap kepuasan masyarakat(Y).

\section{d. Uji Persamaan Regresi}

Berdasarkan harga koefisien kualitas pelayanan $\left(\mathrm{X}_{1}\right)$ adalah 0,451 dan Disiplin kerja $\left(\mathrm{X}_{2}\right)$ adalah sebesar 0,524 serta konstanta sebesar 17,274. Berdasarkan perhitungan tersebut maka dapat disusun persamaan regresi sebagai berikut.

$$
\mathrm{Y}=0,347 \mathrm{X}_{1}+0,42 \mathrm{X}_{2}+17,274
$$

Persamaan tersebut menunjukan bahwa jika:

1). Nilai koefisien $X_{1}$ sebesar 0,451 artinya kualitas pelayanan $\left(\mathrm{X}_{1}\right)$ maningkat 1 poin dan nilai disiplin kerja (X2) tetap maka kepuasan masyarakat (Y) akan meningkat 0,451 poin

2). Nilai koefisien $X_{2}$ sebesar 0,524 , artunya disiplin kerja $\left(\mathrm{X}_{2}\right)$ meningkat 1 poin dan nilai kualitas pelayanan $\left(\mathrm{X}_{1}\right)$ tetap maka kepuasan masyarakat $(\mathrm{Y})$ akan meningkat 0,451 poin.

\section{KESIMPULAN}

Dari hasil penelitian yang dilakukan dapat disimpulkan bahwa terdapat pengaruh Variabel kualitas pelayanan dan disiplin kerja secara bersama-sama terhadpa kepuasan masyarakat di kantor Lurah Klender jakarta Timur. Nilai Koefisien korelasi $\left(\mathrm{r}_{\mathrm{Y}(1,2)}\right)$ sebesar 0,671 dan koefisien Determinasi $\left(\mathrm{r}^{2} \mathrm{Y}(1,2)\right)$ sebesar 0,450 , dan $\mathrm{F}_{\text {hitung }} 49,989$ $>\mathrm{F}_{\text {tabel }}$ 3,07 pada tarap signifikansi 5\%. Besarnya pengaruh kualitas pelayanan dan disiplin kerja secara bersama-sama sebesar 45,6\%. Dan sebesar 54,4 di pengaruhi oleh faktor lain.

\section{REFERENSI}

Atmaja, J. (2018). Kualitas Pelayanan dan Kepuasan Nasabah Terhadap Loyalitas pada Bank BJB. Jurnal Ecodemica: Jurnal Ekonomi , 49-63.

Echdar, S. (2017). Metode Penelitian manajemen dan Bisnis. Bogor: ghalia Indonesia.

Irawan, R. d. (2018). Pengaruh Disiplin Terhadap Kinerja Karyawan pada PT Relasi abadi Jakarta. Widyia Cipta - Jurnal Sekertaris Dan Manajemen, 1-7.

Nurhadi. (2017). Pengaruh Pelayanan dan Produk Jasa Terhadap Komitmen penerimaan Nasabah pada Bank BRI Tigaraksa. Jurnal Moneter , 84-90.

Pardede, R. d. (2014). Analisis Jalur ( Path analysis). Jakarta: PT Rineka Cipta.

Rangkuti, F. (2013.). Customer Service Satisfaction and Call Center berdasarkan ISO 9001. . Jakarta:: PT Gramedia Pustaka Utama.

Ratminto, d. A. (2015). MAnajemen Pelayanan Prima. Yogyakarta: Pustaka Pelajar.

Safudin, M. (2017). Pengaruh Penerapan Absensi Online Terhadap Disiplin pada Karyawan Purple Express Laundry Jakarta. IJSE _ 
Indonesia Journal on Software Engineering, 14.

Savitri, W. D. (2017). Pengaruh Harga, Produk dan Kualitas pelayanan Terhadap kepuasan Konsumen Dwi jaya Furniture. Jurnal Ilmu dan Riset manajemen .

Sugiyono. (2016). Metode Penelitian Administrasi . Bandung: CV Alfabeta.

Suharsimi, A. .. (2010). Prosedur Penelitian Suatu Pendekatan Praktik. Jakarta: Rineka Cipta.

Sutrisno, E. (2017). Manajemen Sumber Daya Manusia. Jakarta: Kencana Prenada Media Grup.

Tjiptono, F. (2014). Cervice Manajemen Mewujudkan Layanan Prima. Yogyakarta: CV Andi Offset.

Widiyanti, W. (2017). Pengaruh Motivasi kerja Terhadap Kinerja Pegawai Pada Dinas Kependudukan dan pencatatan Sipil Kota Depok. Cakrawala- Jurnal Humaniora, 132138.

\section{PROFIL PENULIS}

Eulin Karlina, S.Pd, MM lahir di Cirebon, menyelesaikan S1 tahun 2006 dengan Program studi Pendidikan akuntansi pada Universitas Swadata Gunung Jati Cirebon,. Menyelesiakan S2 tahun 2012 dengan Program studi Magister Manajemen pada Universitas BSI Bandung. Bekerja di Universitas Bina Sarana Informatika dari tahun 2010 sampai sekarang. Selain mengajar juga terdaftar sebagai anggota Asosiasi Dosen Indonesia (ADI) sejak tahun 2017

Oki Rosanto, S.Sos, M.M. Penulis lahir di Jakarta 6 Oktober 1968. Lulus Strata 1 dari Universitas Diponegoro, Semarang dari Fakultas Ilmu Sosial dan Ilmu Politik dengan jurusan Administrasi Niaga. Kemudian dilanjutkan dengan kuliah Strata 2 di Fakultas Pasca Sarjana Universitas Budi Luhur, Jakarta dengan mengambil konsentrasi Manajemen Pemasaran. Aktif mengajar di STMIK Nusa Mandiri tahun 2016 dan mendapat kesempatan mengajar di UBSI pada Fakultas Eonomi dan Bisnis sejaktahun 2016.

Nur eka Saputra, A.Md lahir di Jakarta. Menyelesaikan studi D3 pada tahun 2018 dengan program studi Dministrasi Bisnis pada Universitas Bina sarana Informatika. Pernah bekerja CV Devina sebagai staf Administrasi Surat pajak pada tahun 2013. 